\title{
Morphometric and geological conditions for sediment accumulation in the Udava River, Outer Carpathians, Slovakia
}

BARABAS Dušan ${ }^{1}$, BÓNA Ján ${ }^{2}$, KLEIN Daniel ${ }^{3}$, BALÁŽOVIČOVÁ Lenka ${ }^{4}$

1. Pavol Jozef Šafárik University, Institute of Geography, Faculty of Science, Jesenná 5, 04001 Košice, Slovakia;

2. Kpt. Jaroša 13, 04022 Košice, Slovakia;

3. Pavol Jozef Šafárik University, Institute of Mathematics, Faculty of Science, Jesenná 5, 04001 Košice, Slovakia;

4. Matej Bel University, Institute of Geography and Geology, Faculty of Natural Sciences, Tajovského 40, 974 01 Banská Bystrica, Slovakia

\begin{abstract}
The accumulation of sediment in river channels is a phenomenon that is not only influenced by the channel morphology, but also by the physical and geographical characteristics and the endogenous and exogenous processes taking place in the catchment. This paper presents an analysis of the impact the changes in lithological conditions have on the morphological and morphometric parameters of the Udava River channel and their relation to the channel accumulation forms representative of the river's longitudinal profile as well as of its planform. Results document when accumulation forms occur and what is their spatial distribution within the longitudinal and cross-sectional river profiles. More resistant structures created sections with a lower degree of sedimentation, while in depression segments the degree of sedimentation was higher. With the increase in longitudinal slope, the impact of channel width on the average channel bar size increased. Also a difference in the accumulation was observed between the left and right bank which could be possibly explained by the impact of Coriolis force.
\end{abstract}

Keywords: Flysch Carpathians; Udava River; river channel; channel bar; accumulation; longitudinal profile

\section{Introduction}

Morphometric and lithological influence on the river channel form has been widely analysed and discussed in previous research (e.g. Gilbert, 1917; Schum, 1979; Macura et al., 1995; Hey, 1997; Brierley and Fryirs, 2005). Mostly these works aimed to establish the relationship of morphological and morphometric parameters, or the relation to the quantity and parameters of suspended sediment and bedload (Buffington and Montgomery, 1999; Gordon et al., 2004). Works specifically devoted to the observation of the relationship of river morphometry and morphology to the properties and occurrence of channel accumulation forms

Received: 2016-10-11 Accepted: 2017-02-24

Author: BARABAS Dušan, dusbarabas@gmail.com 
alongside the entire river channels were, however, not identified by the authors.

If we consider the whole stream from its source to its estuary to be of the highest hierarchical level (Lehotský and Grešková, 2005), then the river system can be defined as a composition of subsystems, which are interconnected with material and energy flows (or choric relations). An analysis of one subsystem (i.e. segment, zone, channel or alluvial unit) defines the subsystem properties in a vertical direction (topical relations) or it may partially cover the properties of the input parameters. It is questionable whether an analysis of one segment can be regarded as representative of the whole system or whether the impact of the analysed segment on the adjacent segments can be predicted. Therefore this paper presents an analysis of the impact the changes in lithological conditions have on the morphological and morphometric parameters of the Udava River channel and their relation to the channel accumulation forms representative of the river's longitudinal profile as well as of its planform.

Intensive basic geological research has been carried out in the study area since the second half of the last century (Leško, 1951, 1952c, 1957, 1958; Demovič et al., 1954; Leško et al., 1964a, 1964b; Leško and Slávik, 1967). Synthesising works with a wider regional view (Leško et al., 1964a, 1964b; Matějka et al., 1964a, 1964b; Leško and Samuel, 1968; Koráb and Ďurkovič, 1978) and regional geological maps at a scale of 1:50,000 (Koráb, 1983; Žec et al., 2006, 2011) contribute results to the partial investigations. General knowledge about the geological structure of the wider area can be found on the updated map sheet 28 - Svidník within General Geological Map of the Slovak Republic at a scale of 1:200,000 (Potfaj et al., 2008) with explanations (Potfaj et al. in Bezák et al., 2009).

In the past, geomorphological research in this area focused on the river piracy, morphostructures, paleogeographic evolution and neotectonics. The river piracy in the Laborec catchment was described in Leško (1952a, 1952b) and Leško (1952c) also analysed geological factors responsible for the land formation in the wider area. Hromádka (1956) identified the Nízke Beskydy Mts. as a transversal depression between Western and Eastern Carpathians, which was followed by the subsequent characterisation of the genesis of the mountain by Mazúr and Kvitkovič (1963) and Kvitkovič in Leško et al. (1964b). Further geomorphological research associated with mapping and morphogenesis west of Ondavská Highland was published by Harčár (1995, 1997 and 1998). Jakál et al. (1992) analysed radar recordings from the central part of Laborec Highland to examine the effect of structural and lithological factors on the nature of landform. The analysis of morphostructures of Eastern Flysch Carpathians was presented by Dzurovčin and Harčár (2000, 2002). One of the first works reflecting the impact of neotectonics on the Nízke Beskydy Mts. landform was done by Harčár (2002). A study by Vojtko et al. (2012) presents results of multidisciplinary approach towards knowledge of neotectonic development of the northern part of the Laborec catchment. Lacika and Lehotský (2013) outlined paleographic reconstruction of the Laborec catchment based on the analyses of geomorphological networks.

Present research concerns the correlation of channel slope, channel width and the intensity of sedimentation forms on the Udava River in Eastern Slovakia. The first reason for choosing this river as a study site was that it flows through significant (passive) morphostructures (Lacika and Lehotský, 2013). The alternation in morphostructures provides conditions for varied changes within the long profile that is the first driving mechanism influencing the intensity of sediment accumulation (Figure 1). Secondly, this river is relatively 
undisturbed with natural river processes preserved. And thirdly the anthropogenic land use in the catchment is of a low degree, which has a positive effect on runoff, erosion and accumulation processes. The results presented in this paper are compared to similar studies undertaken in different geological and geomorphologic settings (Barabas and Sýkorová, 2007; Barabas, 2008; Barabas and Frániková, 2009; Kidová and Lehotský, 2012). Additionally, the influence of the Coriolis force on the river channel form is examined.

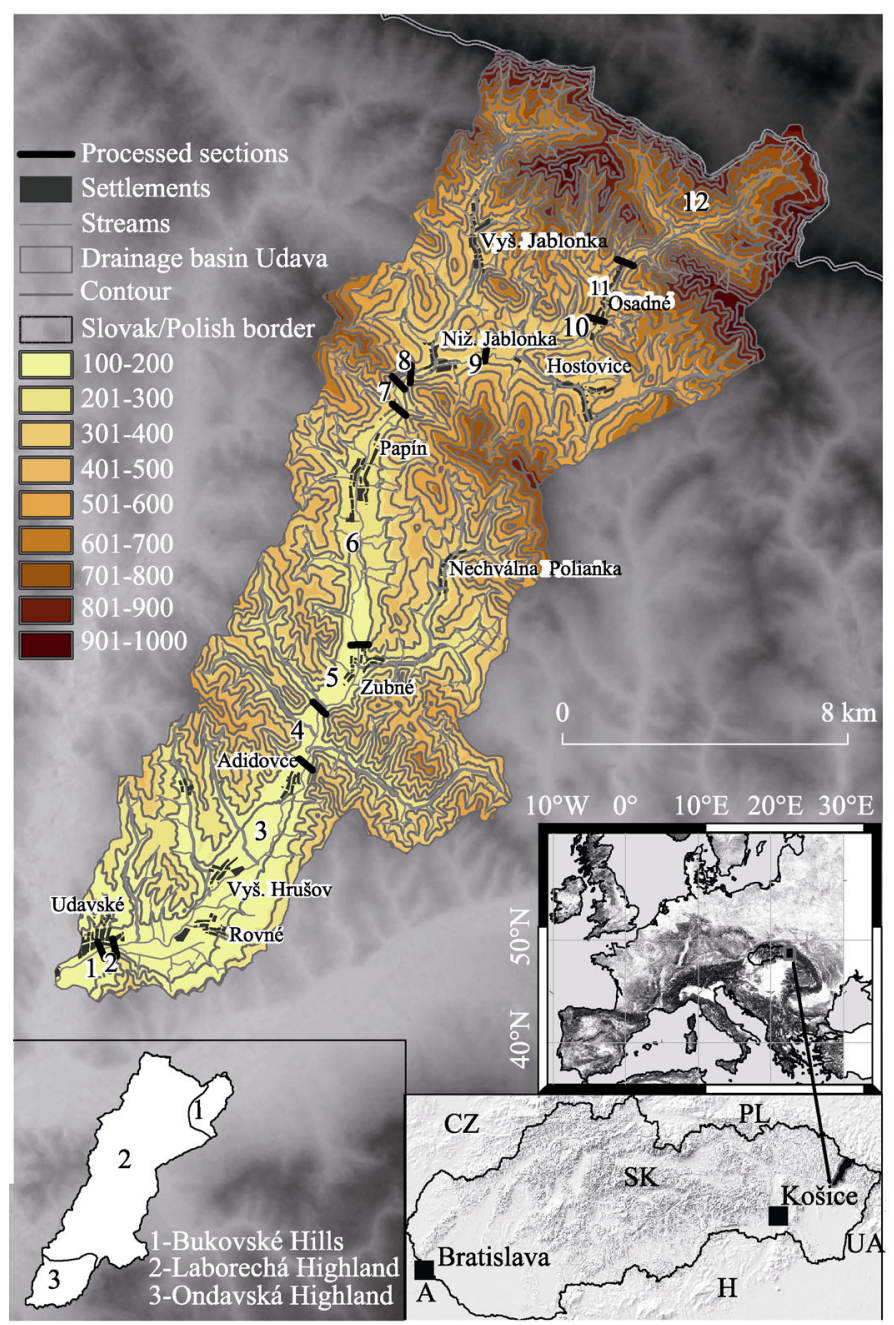

Figure 1 Position of the studied Udava River catchment in relation to geomorphological units showing locations of sections in the longitudinal channel profile

\section{Study area}

Udava River is the second most significant left tributary of the River Laborec, eastern Slovakia. Udava rises at the altitude of $692 \mathrm{~m}$ a.s.l. in Bukovské hills on the Slovak-Polish border. This border also divides the main European catchments. The confluence to the River Laborec is at the altitude of $155.4 \mathrm{~m}$ a.s.l. near the village of Udavské. The length of the Udava River is $38.5 \mathrm{~km}$, the length of the entire river network is $384.16 \mathrm{~km}$ and the catch- 
ment covers an area of $221.41 \mathrm{~km}^{2}$.

The catchment of Udava has unilateral asymmetry. In the longitudinal profile in the upper catchment to Nižná Jablonka strong right asymmetry prevails due to the tributary Rieka. From Papín to Adidovce left asymmetry is dominant with more significant tributaries Nechválka and Ilovnica. At the bottom part from Adidovce to the confluence with Laborec, right asymmetry prevails (Figures 1 and 2). The alternation of these reaches can be associated with tectonics and parallel streams that constitute together strongly asymmetric river network of the River Laborec (Vojtko et al., 2012).

\subsection{Geology}

The northern part of the study area (Figure 2a) is represented by the Dukla Unit, the southern part by the Magura Nappe. From the tectonic point of view, they represent a part of the folded collisional accretionary prism of the External Carpathians. Their lithological filling is

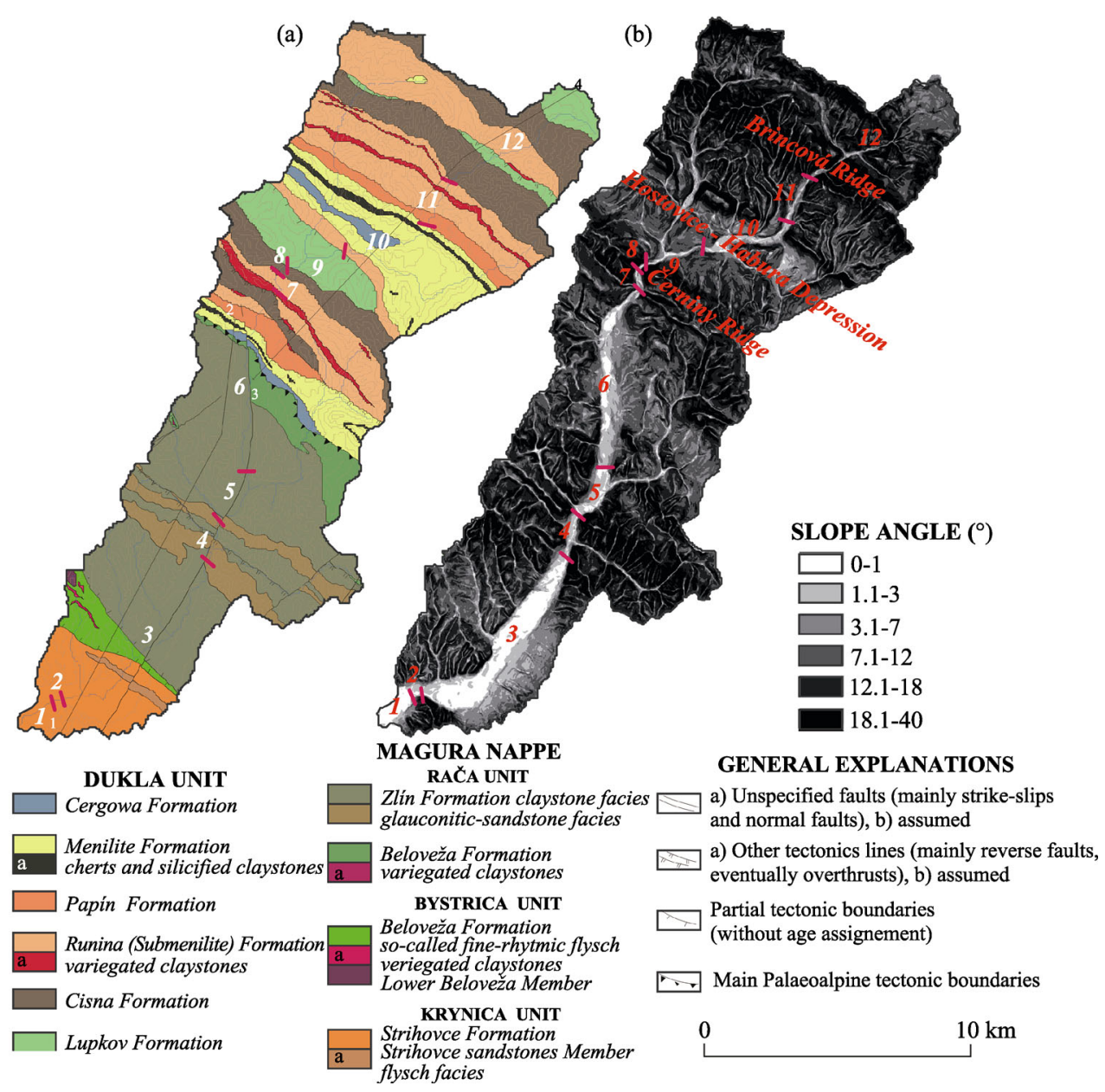

Figure 2 Geological map of the study area without Quaternary deposits. Modified according to Koráb et al., 1966; Koráb, 1983; Žec et al., 2006 (a), and Slope map - the slopes were computed using DTM and were divided to six slope angle categories (b) 


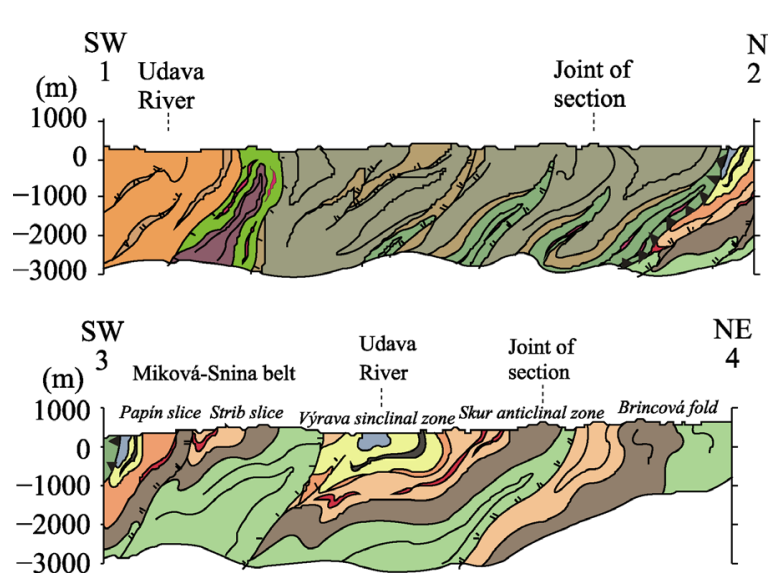

Figure 3 Geological cross-sections 1-2 and 3-4. (See legend on Figure 2)
$\mathrm{N}$ formed by Upper Cretaceous-Oligocene (Leško and Samuel, 1968; Potfaj et al., 2008; Bezák et al., 2009) deep-sea with predominantly siliclastic sediments.

The Dukla Unit represents a separate structural zone within the Carpathian Flysch Belt. It can be characterised as a system of folds and anticlinal slices which course is generally orientated in NW-SE direction. Within the framework of the study area from north to south, following sub-tectonic structures, can be distinguished (Figures 2a and 3): Brincová fold, Skur anticlinal zone, Výrava sinclinal zone, Miková-Snina belt - Strib slice and Papín slice. The contact of the Dukla Unit with the Magura Nappe is tectonic (e.g. Koráb and Durkovič, 1978).

Within the lithostratigraphic profile of the Dukla Unit (Koráb and Durkovič, 1978; Potfaj et al. in Bezák et al., 2009), the Lupków Formation (Senonian - Paleocene) is the oldest stratigraphic member which consists of claystone-sandstone flysch with black and gray claystones predominating by $60 \%-90 \%$ over sandstones. The youngest part of the Dukla Unit consists of fine-rhythmic flysch of the Cergowa Formation (Lower Oligocene), which is characterized by alternation of gray and brown calcareous claystones with laminated fine-grained sandstones.

From the north to the south, the Magura Nappe can be divided into three tectonic-litofacies subunits (cf. Žec et al., 2006; 2011; Potfaj in Bezák et al., 2009): the Rača, Bystrica and Krynica units, each of them with specific lithostratigraphical filling: (1) The Rača Unit is the most extensive in the studied area. It is built by the framework of synclinal, anticlinal zones and overthrusts. At the bottom, it is formed by thin-bedded flysch with layers of variegated claystones and is referred to as the Beloveža Formation (Late Palaeocene Middle Eocene). The Superjacent Zlín Formation (the Midde to Late Eocene) is divided into two facial developments - claystone facies (calcareous claystones and siltstones with glauconitic sandstone intercalations) and glauconitic sandstone facies (glauconitic sandstones with layers of calcareous claystones and siltstones). (2) The Bystrica Unit is situated in a narrow tectonically reduced band between the Rača and Krynica units. Beloveža Formation (Late Palaeocene - Middle Eocene) is developed at the bottom of this unit. Layer sequence begins by a quartzy to arkosic sandstones with conglomerate layers, siltstone and claystone intercalations passing towards the superjacent into claystones to clayeyshales with sandstone beds so-called fine-rhythmic flysch with variegated claystone layers. (3) The Krynica Unit is represented by the Strihovce Formation (the Early - Middle Eocene), which consists of quartz-greywacke sandstone (conglomerate) with siltstone and claystone layers - the Strihovce sandstones member and Flysch facies - claystone with sandstone beds (fine and medium rhytmic flysch).

\subsection{Geomorphologic setting}

The catchment of Udava belongs to the geomorphological province of Eastern Carpathians, 
the subprovince Outer Eastern Carpathians (Mazúr and Lukniš, 1980). According to the classification by Strahler (1952), Udava is a river of the 7th order. The rivers of Udava, Cirocha and Laborec comprise a significant drainage fan (Leško, 1952b) draining the most of the Laborecká Highland, western part of the Bukovské Hills and the eastern part of the Ondavská Highland. In the headwaters area all the way to Osadné, Udava drains the western edge of Bukovské Hills and eastern edge of Laborecká Highland, downstream from Osadné up to Adidovce it drains Laborec Highland. Downstream from Adidovce to the confluence with the River Laborec it drains the eastern part of Ondavská Highland (Figure 1).

The current drainage basin was formed during the younger Alpine orogeny that was typical by tectonic breaks orientated in the NE - SW or in the NW - SE direction. Later on, the distribution of hydrological networks in wider area was affected by the activity during the Neotectonic phase (Harčár, 2002; Vojtko et al., 2012). Several generations of planed surfaces described by Dzurovčin and Harčár (2000 and 2002) provide evidence of a phased lifting area. The evolution of the area is associated with selective erosion that marked the landform by a system of alternating anticlinal ridges and erosion valleys (Leško, 1952a; Dzurovčin and Harčár, 2000). Complicated construction of the area together with tectonics and rocks of varied resistance influenced the development of structured longitudinal river profile. The alternation of sections of anticlinal ridges and synclinal depressions (Figure $2 b$ ) created conditions for changes in the longitudinal profile.

Mountain ridges orientated in the NW-SE or in the WNW-ESE direction (Figures 1, 2a and $2 b$ ), are aligned with the main structure of the folded collision prism of flysch Carpathians. The highest point is Černiny (929.4 m a.s.1.) in the NE part of the territory, towards the SW the altitude drops to $155.4 \mathrm{~m}$ a.s.l. at the point of the confluence of the Udava River with the River Laborec.

Morphostructures on the border with Poland are considered a landscape of massive structures with weak and moderate effect on lithology with fluvially cut highland (Mazúr, 1980; Mazúr et al., 1980). The area south-west of the line Vyšná Jablonka, Osadné and Adidovce formed a landscape of differentiated structures with moderate to severe effect of lithology with fluvial-denudation relief formed by erosional depression (Mazúr, 1980). This area is also referred to as the Hostovice-Habura depression by Leško (1952b, 1952c) and Vojtko et al. (2012). The area between Hostovice and Papin is defined as significant complex morphostructures with brachysynclinal internal structure and tectonic predisposition known as the Hostovice brachysynclinal (Dzurovčin and Harčár, 2000). The landscape formed as differentiated structures with moderate to intensive effect of lithology with fluvially cut and lifted highlands (Mazúr, 1980; Mazúr et al., 1980).

Morphostructure between Papín and Zubné is lined with a landscape of differentiated structures with moderate to severe effect of lithology with fluvially denudated relief formed by erosion gullies. The part of the Udava catchment area between Zubné and Adidovce is formed by highland erosion-denudation landscape of moderate to severe effect of lithology. The downstream part of the Udava catchment is filled with morphostructures of transverse depression of Nízke Beskydy Mts. with relief of pediment hilly lands in the mouth of the Udava River (at about 1.5 river $\mathrm{km}$ ), supplemented by a fluvial cut pediment piedmonts. This led to a change in the longitudinal slope profile (Mazúr, 1980). 


\section{Methods}

Measurements of flow accumulation forms in the Udava River were taken during July and August 2009 to capture the accumulation forms at their largest extent, because the flow rate was only $21 \%-38 \%$ of the average annual flow (SHMÚ, 2009), (Figure 1). Channel width and depth measurements were taken for sections in $50 \mathrm{~m}$ intervals along the entire river to capture changes in the formation of accumulation forms in detail. Evaluation of presence of accumulation forms was processed in $100 \mathrm{~m}$ intervals and related to the changes in the channel slope. Their proportions using a field distance meter and position of channel bars were also recorded (as central, left or right bar). The depth of water was measured with a surveying rod. The basic unit used for the statistical evaluation was the estimated average size of the channel bar area per $100 \mathrm{~m}$ of channel length. At the points of significant changes in longitudinal channel profile (established from the 1:10,000 topographic map), the data were correlated to the geological and tectonic boundaries and based on these, the river was divided into 12 sections (Figures $2 \mathrm{a}, 2 \mathrm{~b}$ and 3 ).

The final part of data evaluation was a cluster analysis that looked at the longitudinal profile divided into two parts (Figure 4) to consider the change (decrease) in the average bar surface area. For the analysis of the impact of parameters in the measured section on the average bar area, a model for each section was used (Table 3 ). This model was used for relating the channel width and slope to the average size of the channel bars in the 100 meter sections (Figure 5 and Table 4). To assess the spatial position of bars in the channel planform, Kendall coefficient of concordance of $\mathrm{W}=0.439(\mathrm{p}<0.001)$ was used, which value allowed to reject the hypothesis of the compliance of division of accumulation forms (location and size). At the same time, this value allowed for a consideration of the impact of Coriolis force on the riverbed and also the shape of the catchment, which could also confirm the hypothesis of asymmetric basin (Figure 4 and Table 6).

To characterise longitudinal and cross sectional profiles of the valley, the following equation was used

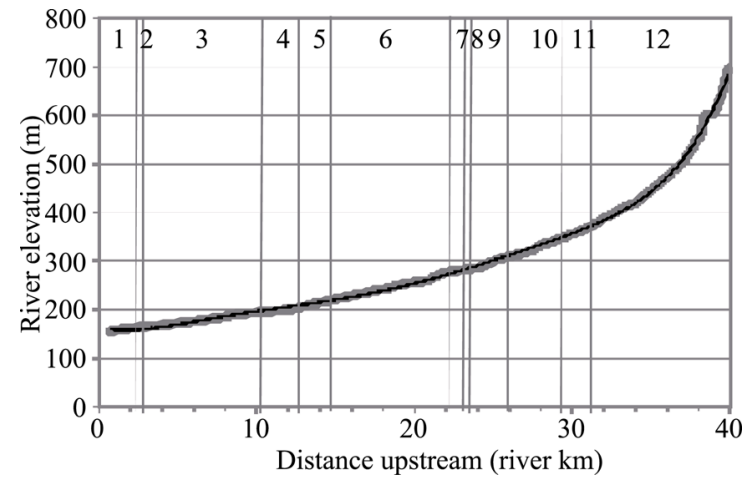

Figure 4 Differences in empirical (thicker grey line) and polynomial (thin black line) longitudinal profile of the Udava River from its confluence to the headwaters illustrating the tectonic dynamics or morphostructural heterogeneity of the catchment

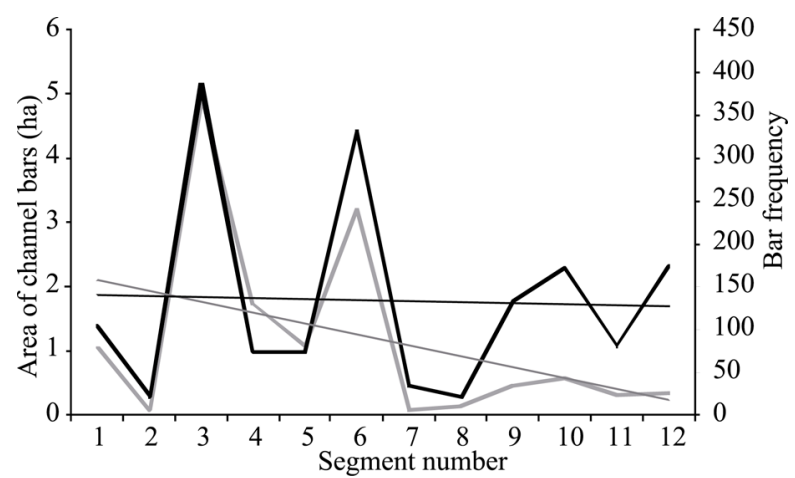

Figure 5 Change in surface area (in grey) and frequency of channel bars (black line) in each catchment studied sections of the Udava River with a corresponding linear regression 
(Hack, 1973):

$$
S L=\frac{\Delta H}{\Delta L} L
$$

where $S L$ is the stream gradient index, $\Delta H(\mathrm{~m})$ is the difference in heights at both ends of the observed river section, $(\mathrm{m})$ is the length of the observed section and $L(\mathrm{~m})$ is the distance from the source to the middle of the given section.

Index values provide means for comparing the changes in the gradient of the researched sections which would be otherwise difficult to establish visually (Table 6). The values of the stream gradient index point out to rapid changes in river gradient in response to the changes in lithology or tectonics.

To describe the proportions of the river valley, $V_{f}$ index was used, defined as the relationship between the height and the width of the catchment valley (Bull and McFadden, 1977; Keller and Pinter, 1996):

$$
V_{f}=\frac{2 S_{d}}{\left(V_{l}-V_{d}\right)+\left(V_{r}-V_{d}\right)}
$$

where $V_{f}$ is the index of ratio of the catchment boundary altitude to the valley width in the given segment, $S_{d}$ is the width of the valley bottom, $V_{l}$ is the altitude of the left channel boundary line, $V_{p}$ is the altitude of the right channel boundary line and $V_{d}$ is the altitude of the valley bottom in the given segment.

Low index values indicate that the stream is predominantly eroding or it can predict a tectonic uplift area. High index values can point out to prevailing lateral erosion increasing the valley width with lower elevation of catchment boundaries with weak tectonic activity. This of course very closely relates to the morphometry of river channel and to the material sedimentation. For the analysis of longitudinal profile, in addition to the comparison of empirical and theoretical longitudinal profile which document changes at the individual sections as well as the deviation from the ideal longitudinal profile, the line of frequency of river section types was used. This line correlates with changes in the slope and it is a very good indicator of changes in lithological and tectonic conditions in the longitudinal profile.

\section{Results}

\subsection{Morphometric analysis of the river channel and the catchment}

Comparison of empirical longitudinal profile of the stream (based on 1:10,000 contour maps) and theoretical longitudinal profile described by a 5th degree polynomial function showed some differences (Figure 4). Areas where lines of empirical and theoretical longitudinal profiles crossed correspond well with the slightly uneven development of the longitudinal profile, tectonic dynamics or morphostructural heterogeneity. It also has great significance for the spatial differentiation of accumulation forms in the channel.

By dividing the catchment alongisde the river channel into two parts slight differences in each half were found. The right side with an area of $114.5 \mathrm{~km}^{2}$ was larger, compared to the left side of $106.9 \mathrm{~km}^{2}$, by $6.7 \%$. The density of river network derived from processed data was $1.74 \mathrm{~km} / \mathrm{km}^{2}$ (the national average is $1.17 \mathrm{~km} / \mathrm{km}^{2}$ ). The river network density is influenced by the low average length of tributaries (only $0.8656 \mathrm{~km}$ ) which drain shorter slopes formed by diversified flysch complex. 
Along the $38.6 \mathrm{~km}$ from its source to the confluence with the River Laborec, the altitude of Udava drops by $536.6 \mathrm{~m}$. This creates good condition for intensive river bed erosion. Laborec from the mouth of Udava to Eastern Lowland (Leško, 1952b) along $12.5 \mathrm{~km}$ drops by $5.19 \mathrm{~m}$ in elevation. The average slope of the Udava longitudinal profile is $0.815^{\circ}$ which creates conditions for accumulation of sediment that originates in the process of deep and lateral erosion at higher inclinations. The changes in longitudinal profile occur where segment boundaries, geological (lithological) and also tectonic boundaries occur within the catchment (Figures 2a and 2b). Influence of geological and tectonic conditions on the channel slope is evident also from DTM. This created basis for division of river reach into 12 sections which exhibit changes in the frequency and surface area if accumulation forms (Figures 1, 4 and Table 1).

\subsection{Hydromorphological analysis}

Accumulation forms in the individual segments of the Udava River (Figure 1 and Table 1) are not uniformly distributed. In the longitudinal profile, significant changes in the frequency and area of accumulation forms have been observed (Figure 6). Similarity in the

Table 1 Basic morphologic and morphometric characteristics of the individual segments of the Udava River

\begin{tabular}{lccccccc}
\hline Size of segment & $\begin{array}{c}\text { Average } \\
\text { number of } \\
\text { channel bars }\end{array}$ & $\begin{array}{c}\text { Average slope } \\
\left({ }^{\circ}\right)\end{array}$ & $\begin{array}{c}\text { Surface area } \\
\text { of channel } \\
\text { bars }\left(\mathrm{m}^{2}\right)\end{array}$ & $\begin{array}{c}\text { Number of } \\
\text { channel } \\
\text { bars }\end{array}$ & $\begin{array}{c}\text { Average surface } \\
\text { area of channel } \\
\text { bars }\left(\mathrm{m}^{2}\right)\end{array}$ & $\begin{array}{c}\text { Surface area } \\
\text { of river } \\
\text { channel }\left(\mathrm{m}^{2}\right)\end{array}$ & $\begin{array}{c}\text { Channel } \\
\text { width }(\mathrm{m})\end{array}$ \\
\hline $1(0-1929)$ & 5.5 & 0.335 & 10505.36 & 104 & 101.0131 & 20080 & 10.6 \\
$2(1929-2343)$ & 6 & 0.21 & 801.98 & 22 & 36.45 & 4730 & 11.8 \\
$3(2344-10910)$ & 4.51 & 0.225 & 49351.89 & 387 & 127.520 & 123720 & 9.9 \\
$4(10911-12640)$ & 4.35 & 0.291 & 17269.04 & 74 & 233.37 & 13940 & 8.7 \\
$5(12641-14884)$ & 3.17 & 0.433 & 10658.21 & 73 & 146.00 & 23850 & 10.37 \\
$6(14885-22609)$ & 4.31 & 0.416 & 32074.63 & 332 & 96.61 & 76190 & 9.9 \\
$7(22610-23510)$ & 3.78 & 0.567 & 913.24 & 34 & 26.86 & 6670 & 7.4 \\
$8(23511-23943)$ & 5.25 & 0.79 & 1500.72 & 21 & 71.46 & 3410 & 8.5 \\
$9(23944-26333)$ & 5.54 & 0.53 & 4542.66 & 133 & 34.16 & 16720 & 6.97 \\
$10(26334-29850)$ & 4.78 & 0.929 & 5896.43 & 172 & 34.28 & 19050 & 5.3 \\
$11(29851-31829)$ & 4.26 & 1.005 & 3031.02 & 81 & 37.42 & 10050 & 5.3 \\
$12(31830-38614)$ & 2.64 & 2.491 & 3347.76 & 174 & 19.24 & 16260 & 2.4 \\
\hline
\end{tabular}

Table 2 Average monthly discharges in 2009 and maximum and minimum discharges in profiles Papín and Udavské in 2009 and in the long term (SHMÚ, 2009)

\begin{tabular}{|c|c|c|c|c|c|c|c|c|c|c|c|c|c|}
\hline Months & I & II & III & IV & V & VI & VII & VIII & IX & $\mathrm{X}$ & XI & XII & Year \\
\hline Papín & 1.602 & 0.827 & 2.920 & 1.364 & 0.387 & 0.442 & 0.246 & 0.418 & 0.267 & 1.312 & 1.915 & 1.817 & 1.130 \\
\hline Udavské & 2.146 & 1.202 & 3.457 & 2.168 & 0.693 & 0.593 & 0.387 & 0.543 & 0.434 & 2.013 & 2.903 & 3.187 & 1.649 \\
\hline & & & \multicolumn{4}{|c|}{$\left.\mathrm{Q}_{\max } \mathrm{m}^{3} \cdot \mathrm{s}^{-1}\right)$} & \multicolumn{3}{|c|}{ Year } & \multicolumn{4}{|c|}{$\mathrm{Q}_{\min }$} \\
\hline \multirow{2}{*}{\multicolumn{3}{|c|}{ Papín }} & \multicolumn{4}{|c|}{$37.90 \mathrm{~m}^{3} \cdot \mathrm{s}^{-1}$} & \multicolumn{3}{|c|}{2009} & \multicolumn{4}{|c|}{$0.083 \mathrm{~m}^{3} \cdot \mathrm{s}^{-1}$} \\
\hline & & & \multicolumn{4}{|c|}{$270.00 \mathrm{~m}^{3} \cdot \mathrm{s}^{-1}$} & \multicolumn{3}{|c|}{ 1966-2008 } & \multicolumn{4}{|c|}{$0.025 \mathrm{~m}^{3} \cdot \mathrm{s}^{-1}$} \\
\hline \multicolumn{3}{|c|}{ Udavské } & \multicolumn{4}{|c|}{$51.59 \mathrm{~m}^{3} \cdot \mathrm{s}^{-1}$} & \multicolumn{3}{|c|}{2009} & \multicolumn{4}{|c|}{$0.186 \mathrm{~m}^{3} \cdot \mathrm{s}^{-1}$} \\
\hline & & & \multicolumn{3}{|c|}{$217.50 \mathrm{~m}^{3} \cdot \mathrm{s}^{-1}$} & & \multicolumn{3}{|c|}{$1975-2008$} & \multicolumn{4}{|c|}{$0.063 \mathrm{~m}^{3} \cdot \mathrm{s}^{-1}$} \\
\hline
\end{tabular}


Table 3 Statistical importance of the average size of channel bars in a given section of the studied stream

\begin{tabular}{cccccc}
\hline \multirow{2}{*}{ Measured section } & \multicolumn{2}{c}{$\leqslant 19.5 \mathrm{~km}$} & & \multicolumn{2}{c}{$19.5-38.6 \mathrm{~km}$} \\
\cline { 2 - 3 } \cline { 5 - 6 } & Resizing bar & Sig. & & Resizing bar & Sig. \\
\hline Section & -0.0000079 & 0.613 & & -0.000194 & $0.000^{* * *}$ \\
\hline
\end{tabular}

$* p \leqslant 0.05 ; * * p \leqslant 0.01 ; * * * p \leqslant 0.001$ (2-tailed)

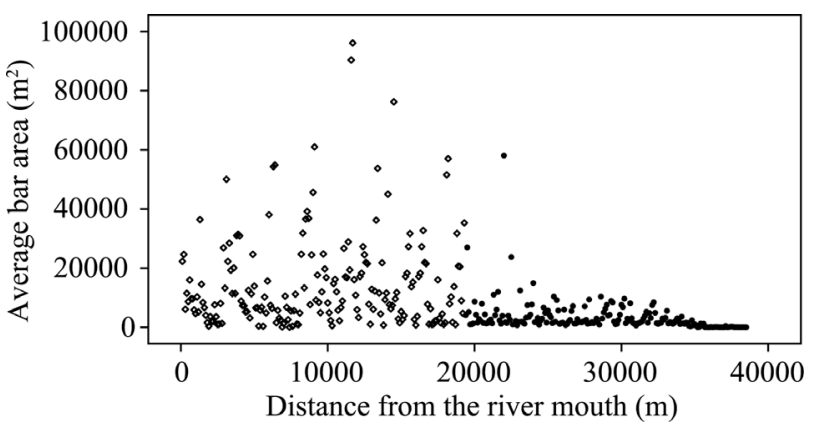

Figure 6 Average channel bar size recorded every $100 \mathrm{~m}$ on the Udava River from the confluence with the River Laborec, divided into the two sections based on the cluster analysis number of accumulation forms was recorded in sections $4,6,7,9,10,11$ and 12 , but section 6 was considerably different. This created a basis for the statistical division of the dataset (Figure 6 and Table 3). In the first section, after about $19.5 \mathrm{~km}$ (from the mouth of Udava to Laborec segments 1 to 6 ), the mean value of channel slope was $0.3^{\circ}$. In this section, higher number and total area of channel bars was present (Table 1), apart from sections 4 and 5. In segment 4, Udava cuts through more resistant morphostructure impaired by thrust-belt Krivá Ol'ka line (Pesl and Menčík, 1959; Pesl, 1964; Žec et al., 2011, cf. Figures 2a and 2b) formed by sediments of glauconitic-sandstone facies of Zlín Formation. This is reflected by the lower frequency and surface area of channel bars. Along the second river reach from the river $\mathrm{km} 19.5$ (sections 7 to 12 ) to the source, the slope was $1.3^{\circ}$ on average. In this section, Udava predominantly eroded and transported material, which resulted in reduced frequency and size of accumulation forms. Partially, this is also caused by lower discharges (Figure 9 and Table 1). In segment 10 (south and southwest of the village of Osadné), an anomaly of sudden growth in size and frequency of accumulation forms was recorded. This section is referred to as Hostovice brachysynclinal (Leško, 1952b; cf. Figure 1 and Table 1). Discussed anomaly results from sudden changes in channel slope which creates conditions for better material accumulation (clastic material eroded and transported from higher reaches) in Hostovice-Habura Depression, what establishment is given by lithological factor and erosion of paleoflow (Leško, 1952b; Vojtko et al., 2012). Sections 11 and 12 show a variation between the size and surface of accumulation forms (Figure 5). But because of large slope and small discharges, it is difficult to interpret these.

Generalised linear regression model used to analyse the average size of channel bars showed very similar results and showed a sudden change at about $20 \mathrm{~km}$ from the confluence (Table 3). This confirmed the correctness of the division of the longitudinal profile given in the first phase into the two sections that were tested separately. While in the first section the change in channel bar size was not significant, between 19.5 and $38.6 \mathrm{~km}$ a significant exponential decline was observed.

This statistical difference, which limit is tied to the border between segments 6 and 7 (northeast from Papín) is related to the rapid changes in altitude and to lithological change and tectonic border lines. Further evidence can also be a significant change in the channel 
slope index (SL), as well as the ratio index of the catchment boundary elevation to the valley width $V_{f}$ (Table 4).

Table 4 Entry parameters of slope index and ratio index of the catchment elevation and width in the individual studied sections of Udava River

\begin{tabular}{cccccccccccc}
\hline Sections & $H_{\max }$ & $H_{\min }$ & $\Delta L$ & $L$ & $S_{1}$ & $V_{p}$ & $V_{1}$ & $V_{d}$ & $S_{d}$ & $2 * S_{d}$ & $V_{f}$ \\
\hline 1 & 164 & 155 & 1847 & 37604.1 & 183.2 & 163 & 180 & 161 & 531 & 1062.0 & 50.57 \\
2 & 168 & 164 & 414 & 36473.6 & 352.4 & 170 & 238 & 166 & 553 & 1106.0 & 14.55 \\
3 & 204 & 168 & 8567.8 & 31982.7 & 134.4 & 380 & 290 & 184 & 848 & 1696.0 & 5.62 \\
4 & 214 & 204 & 1729.2 & 26834.2 & 155.2 & 477 & 407 & 207 & 448 & 896.0 & 1.91 \\
5 & 233 & 214 & 2245 & 24847.1 & 210.3 & 393 & 406 & 222 & 511 & 1022.0 & 2.88 \\
6 & 285 & 233 & 7607.1 & 19921.05 & 136.2 & 395 & 620 & 251 & 669 & 1338.0 & 2.61 \\
7 & 288 & 285 & 939 & 15648 & 50.0 & 492 & 522 & 287 & 332 & 664.0 & 1.51 \\
8 & 290 & 288 & 512.3 & 14922.4 & 58.3 & 645 & 590 & 289 & 92.3 & 184.6 & 0.28 \\
9 & 320 & 290 & 2349.7 & 13491.35 & 172.3 & 422 & 668 & 246.2 & 122.8 & 245.6 & 0.41 \\
10 & 358 & 320 & 3558 & 10537.5 & 112.5 & 815 & 460 & 335 & 333.7 & 667.4 & 1.10 \\
11 & 405 & 358 & 1980 & 7769 & 184.4 & 560 & 795 & 375 & 364 & 728.0 & 1.20 \\
12 & 696 & 405 & 6778.5 & 3390 & 145.5 & 837 & 685 & 465 & 11 & 22.0 & 0.04 \\
\hline
\end{tabular}

$H_{\max }$ - maximum elevation of the section, $H_{\min }$ - minimum elevation of the section, $\Delta L$-length of the section, $L-$ distance of the section from the spring to the middle of the given section $\Delta L, S_{1}$ - channel slope index, $V_{p}$ - elevation of the right channel boundary, $V_{1}$ - elevation of the left channel boundary, $V_{d}$ - elevation of the valley bottom, $S_{d}-$ width of the valley bottom, $V_{f}$ - ratio index of the valley elevation and width.

Table 5 Logarithm of the bar area responsible for the unit increase in channel width (m) at the change of stream from small to medium resp. large

\begin{tabular}{lc}
\hline & Change in logarithm of the channel bar \\
\hline Width of the river channel & $0.269 * * *$ \\
Slope middle comparing to slope low & $-1.258^{* * *}$ \\
$\begin{array}{l}\text { Slope high comparing to slope low } \\
\text { Relation of slope with the width of the river channel - Width of river } \\
\text { channel versus slope middle comparing to slope low }\end{array}$ & $-5.063 * * *$ \\
$\begin{array}{l}\text { Relation of the slope with the width of river channel }- \text { Width of river } \\
\text { channel versus slope high comparing to slope low }\end{array}$ & $0.472 *$ \\
\hline$* * * p<0.001, * * p<0.01, * p<0.05$ & $1.533^{* * *}$
\end{tabular}

Similar to earlier results, findings summarised in Table 4 document significant changes that occurred in sections 3, 6, 7 and 10. Slope index, compared with adjacent segments, shows significant changes (Figure 5) that correspond with the area and the quantity of accumulation forms.

Generally accepted influence of the longitudinal profile on accumulation and channel width was analysed with the general linear model. The dependent variable was the logarithm of one bar area at the time of survey. The slope of the river was categorised for $0^{\circ}-0.8^{\circ}$ as slopes with little inclination, for $0.8^{\circ}-2.5^{\circ}$ as medium slopes and for more than $2.5^{\circ}$ as large slopes. To determine whether the effects of slope and the width of the river are additive, we have included their interaction in the model, where the variables were standardised.

The analysis shows a statistically significant effect of the slope on the average size of channel bars. For small and medium slope, the effect of the width on the formation of ac- 


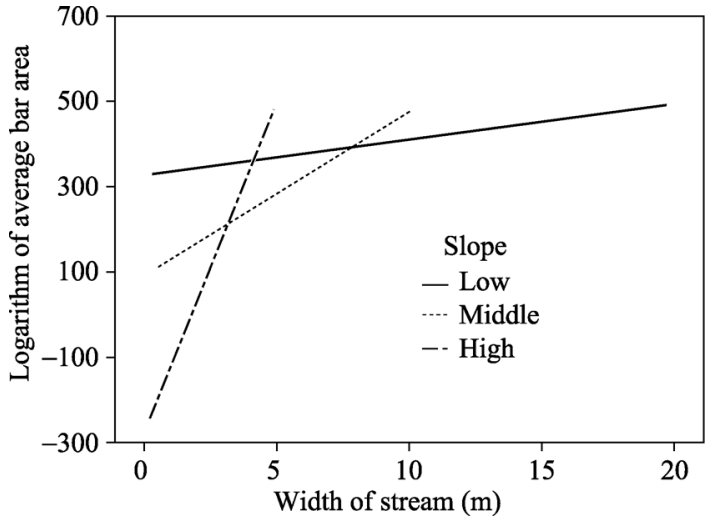

Figure 7 Logarithm of the average bar area in relation to the channel width for slope angle categories: $0^{\circ}-0.8^{\circ}$, $0.8^{\circ}-2.5^{\circ}$ and $>2.5^{\circ}$

cumulation forms is less pronounced even when the size of accumulation forms is greater than in the case of larger gradient. An analysis of Udava also shows that with increasing slope the relationship between average channel bar area and channel width is steeper (Figure 7 and Table 6). When the channel is wider, the channel bar area is greater but the growth of the area with bar width is slower at lower slope compared to greater slope. It points out to a non-additive relationship of these indicators.

To analyse the size of channel bar within the river channel, we tested the null hypothesis: The distributions of right, middle and left size of channel bars are the same. The resulting Kendall's coefficient of concordance was $\mathrm{W}=0.439(p<0.001)$, therefore the null hypothesis was rejected.

Significant differences can be seen between the values of statistical parameters (Table 7). On the left bank, more material was deposited than on the right and in the middle of the channel the least (Figure 8, Tables 6 and 7). The difference in the average size of the accumulation forms on the right and left bank represents about $20 \%$. Significant disparity occurs in the average size of central bars, which represent only about $13 \%-16 \%$ of the size of the right and left-sided bars. Interesting is the 75th percentile for left-sided bars which documents the accumulation forms of larger size than the average value of all bars. In the case of right-sided bars, the value of the 75th percentile is just below average. For central bars, the 75th percentile is less than half of the average of the surface area of central benches. The distribution of basic statistical values for the size of accumulation forms are summarized (Figure 8). The right-sided accumulations compared to the left have a smaller average size.

Table 6 Frequency and average accumulation form area in individual segments of the Udava River

\begin{tabular}{lccccccc}
\hline \multicolumn{1}{c}{ Segment range } & $\begin{array}{c}\text { Frequency } \\
\text { of bars }\end{array}$ & Right bar & Left bar & Central bar $\begin{array}{c}\text { Average area } \\
\text { of bar }\left(\mathrm{m}^{2}\right)\end{array}$ & $\begin{array}{c}\text { Total area of } \\
\text { bar }\left(\mathrm{m}^{2}\right)\end{array}$ & $\begin{array}{c}\text { Average slope } \\
\left({ }^{\circ}\right)\end{array}$ \\
\hline $1(0-1929)$ & 104 & 37 & 46 & 21 & 101.0131 & 10505.36 & 0.335 \\
$2(1929-2343)$ & 22 & 5 & 12 & 5 & 36.45 & 801.98 & 0.21 \\
$3(2344-10910)$ & 387 & 161 & 165 & 61 & 127.520 & 49351.89 & 0.225 \\
$4(10911-12640)$ & 74 & 32 & 26 & 15 & 233.37 & 17269.04 & 0.291 \\
$5(12641-14884)$ & 73 & 29 & 33 & 11 & 146.00 & 10658.21 & 0.433 \\
$6(14885-22609)$ & 332 & 143 & 143 & 46 & 96.61 & 32074.63 & 0.416 \\
$7(22610-23510)$ & 34 & 10 & 18 & 6 & 26.86 & 913.24 & 0.567 \\
$8(23511-23943)$ & 21 & 8 & 10 & 3 & 71.46 & 1500.72 & 0.79 \\
$9(23944-26333)$ & 133 & 63 & 56 & 14 & 34.16 & 4542.66 & 0.53 \\
$10(26334-29850)$ & 172 & 68 & 85 & 19 & 34.28 & 5896.43 & 0.929 \\
$11(29851-31829)$ & 81 & 29 & 40 & 12 & 37.42 & 3031.02 & 1.005 \\
$12(31830-38614)$ & 174 & 65 & 86 & 23 & 19.24 & 3347.76 & 2.491 \\
\hline
\end{tabular}


Table 7 The evaluation of relationship of average size of accumulation forms to the location within the river channel

\begin{tabular}{lccccccc}
\hline \multicolumn{1}{c}{ Bar } & Average & Standard deviation & Minimum & Maximum & 25 percentile & 50 percentile & 75 percentile \\
\hline Right bar & 82.62 & 169.71709 & 0 & 1107.50 & 4.01 & 14.7 & 80 \\
Left bar & 102.73 & 200.56834 & 0 & 1600.00 & 12 & 32.9 & 112.53 \\
Central bar & 13.19 & 54.96708 & 0 & 560.00 & 0 & 0 & 4.88 \\
\hline
\end{tabular}

They also have, compared with rightsided accumulation forms, larger size ranges as the size of the accumulation of left bars. Considering the right-sided accumulation forms, a higher degree of asymmetry in the distribution of area sizes can be observed than in the case of left-sided. Central bars have the lowest average size but the least symmetry in distribution with the largest occurrence of extreme values.

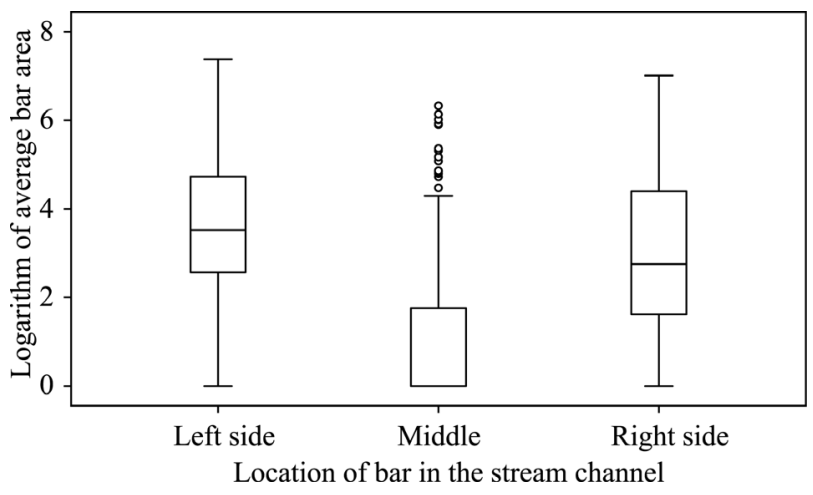

Figure 8 The degree of asymmetry and extreme size of channel bars according to their position in the river channel

\section{Discussion on the relationship between morphometric and hydromor- phologic properties}

The development of drainage network largely depends on the geological and tectonic evolution of the catchment. Its nature and flow regime is also determined by land use within the riparian zone and on the floodplain. Channel accumulation has a great importance for overbank flow. Therefore, we consider evaluating and understanding the spatial distribution of accumulation forms as very important. The presence of accumulation forms in the river channel and the monitoring of their spatial distribution in the longitudinal and transverse profile provide information not only on the conditions of formation of the channel but also of the entire catchment. Each river basin is formed by exogenous and endogenous processes. The endogenous processes are generally of a very low intensity and are less notable. The exogenous processes are intensive and their presence can be identified. These processes are connected and both contribute to the formation of river basin and are well identified in the surface runoff concentration areas. The concentration of runoff in river channel resulted in the formation of morphology given by mechanical energy (kinetic energy flow, pressure potential energy, gravitational potential energy). Therefore, we consider the energy flow, which is an indicator of the slope, as independent variable. Other observed parameters are considered as dependent variables.

Presented results document that the formation of accumulation bars as well as their spatial structure is given by the longitudinal profile (Figure 4). Because the longitudinal profile varies as a result of lithological and geomorphologic factors (geomorphological value of rock of the basement), neotectonic movements, or the impact of anthropogenic factors, it is necessary to understand the relationship of analysed parameters and accumulation forms. Understanding the conditions of accumulation will prevent overbank flow caused by inap- 
propriate interventions into the morphometry of river channels. If we consider the theory of dynamic equilibrium, where size and shape of the river channel under constant hydrological conditions do not change (Leopold, 1997), then the local interventions in the river channel can distort the dynamic equilibrium of the whole river system. For example, this can initiate a response in the dynamics of sedimentation in other parts of river channel, tributaries or the whole catchment, like the flood prevention measures undertaken at Nižná Jablonka, Papin (Jalčovíková et al., 2011).

Dynamics in the longitudinal profile were documented by Leško (1952a) who looked at the river piracy in the upper catchment. He explains the piracy on the basis of difference in flow energy (vertical height difference of the channel on the comparable reach). According to Leško (1952a) rivers affected by piracy on the Polish side have a smaller drop in elevation and thus lesser total energy flux as the Udava River. For this reason, Udava cuts more intensively into the sediment and pushes its channel upstream, thereby cutting the main Carpathian ridge by back erosion.

Results presented in Table 1 illustrate that Udava has an irregular longitudinal profile. The reason is the change in conditions forming the accumulation bars. According to the classification by Rosgen (1994) the longitudinal profile of Udava can be classified into planar type that is below $2^{\circ}$ with instances of riffle and pool sections with a slope of $<4^{\circ}$. Exceptionally, in the headwaters section, pools with slope below $2^{\circ}$ can occur. Changes in these sections can be seen on Figure 9, where the steeper and shallower sections occur. Different flow velocities have different effects on the accumulation processes, its location, size and grain size of the material. In the pool sections, finer sediments occur in contrast with the riffle sections. Significant changes in the proportion of different types of river sections as well as the transition from one type to another largely correspond with the boundaries of individual segments. The rate of change of river sections correspond to the changes in inclination. In the segments, the prevailing type of river reach is preserved which is the step or riffle and pool (Figure 9), given by the geological conditions and the different morphostructures that identify the segment boundaries (Figure 2a).

A very good correlation of the frequency of step, riffle and pool sections with the segment boundaries confirms the relationship with the development of river accumulation forms.

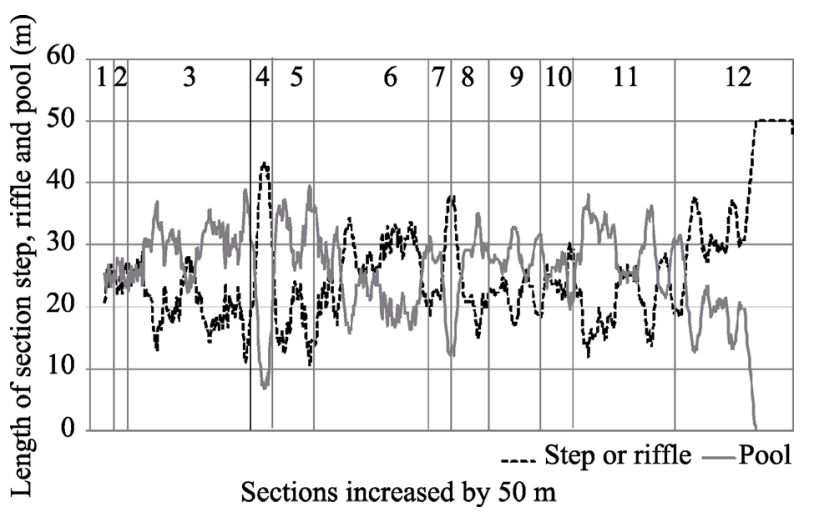

Figure 9 The frequency of river sections step or riffle (in black) and pool (grey) expressed as 20th percentile of moving average
Some distortion can be observed in segments 4, 7 and 10 where segment boundaries were shifted in relation to the river reaches becasue of the method used to present the river reach types. The use of the 20th percentile of moving average shifted the origin of section (step, riffle and pool), which resulted in noncomplete correlation of segment borders and river section types. On the other hand, if we did not use the moving average method, this relationship would be difficult to identify the frequency of 
data change.

The spatial differentiation of action of the total mechanical energy was also considered. The maximum discharge in the upstream profile Papín (19 river $\mathrm{km}$ ) and downstream profile of Udavské (1.8 river km, Figure 1 and Table 2) showed an anomaly. In Udavské the value of $\mathrm{Q}_{\max }$ was lower compared to $\mathrm{Q}_{\max }$ in Papín. Therefore the total mechanical energy in Papín is greater than in Udavské. The comparison of $\mathrm{Q}_{\max }$ brings considerations whether there is a change in morphology possible in the whole profile or whether it depends on episodic events. We assume that it depends on the evolution of catchment landform over time. Schumm and Lichty (1965) define the amount of runoff and sediment as not determined variable for geological periods. For geomorphological period it is determined as an independent variable. However, we would like to question this view. If the slope of the longitudinal profile is regarded as the fundamental parameter on which discharge and total mechanical energy depend, it is difficult to agree with the view that one non-periodic event can cause change in the character of the longitudinal profile or its part, which depends on endogenous and exogenous catchment processes. Therefore we assume that episodic events are more likely to affect channel morphology locally during certain limited time period and we do not expect changes that could be seen as evolutionary of the longitudinal profile.

We analysed the average annual precipitation and average annual discharges and assumed the river transport to be an equal amount of material corresponding with respect to its total mechanical energy during a longer period of time. A constant sediment load allows the same volume of material to accumulate on channel bars, which can get reorganised within the channel. An important question is: What conditions must be present for the channel bar to form? Another relevant question is: Under what conditions or for which combination of morphological parameters the accumulation forms in the riverbed? General opinions and analysis on the empirical relations, theories of sedimentation and regional equations do not provide acceptable and generally valid conclusions (Lehotský, 2005). We consider the river as a dynamic system that constantly changes and endogenous and exogenous processes are its basic independent variables.

Based on these considerations, we have focused on defining the basic relations in the catchment. Definition of these relationships allowed us to understand and partially generalise conditions of transport and accumulation of sediments in the river channel. It also allowed us to point out the influence of geological conditions in the area on forming the longitudinal profile of the channel in the Eastern Slovakian flysch zone of the Outer Western Carpathians. Analysis of the spatial distribution of accumulation forms created preconditions for the practical verification of the influence of Coriolis force. If the effect of the force exists, then more erosion should occur on the right side and accumulation on the left. However, in certain lithological, tectonic or morphometric conditions, this effect may not be evident. The possible signs of the Coriolis force in the estuary of rivers were studied by Dolgopolova and Isupova (2011), Li et al. (2011), Li et al. (2014), who also confirmed the impact of Coriolis force on the river channel. Unger and Németh (2013) observed the impact of Coriolis force on erosion processes in the formation of the Tisza River channel and they also proved the impact of this force.

In general, more robust geological structures create conditions for the elevation of structures within the river basin, which are cut by the river flow. The water forms river channel with steeper longitudinal profile and higher flow energy. Under these conditions, erosion 
prevails with minimum accumulation. In contrast, on less resistant structures, river flow accumulates material and the long profile is less steep with lower total flow energy. In such conditions, formation of wider river bed occurs in comparison with adjacent segments, and also larger surface of accumulation forms (see segments 3, 6, 10 on Figure 2 and Table 1). Tectonics plays a role in this and in the detailed database in places of tectonic faults, the channel slope is higher.

\section{Conclusions}

This paper described the impact of lithological conditions on the morphological and morphometric parameters of the Udava River and their relation to the channel accumulation forms representative of the river's longitudinal profile as well as of its planform. The results show a good correlation between accumulation forms and the longitudinal profile or the channel width. With the increase in longitudinal slope the impact of channel width on the average channel bar size increased. Conversely, drop in river slope caused the channel width to have a decreasing impact on channel bar size. The assumption that the wider channel means larger bar size, where flow energy drops and sediment is likely to accumulate, did not apply generally. Lithological conditions however had significant effect on the sediment accumulation in the individual segments. More resistant structures located in upper part of the catchment made of lithostratigraphic units with a higher presence of mechanically resistant rocks created sections with steeper longitudinal profile and with a predominance of erosion and transport processes over sedimentation. On the contrary, depressions built in less resistant lithostratigraphic units had higher presence of accumulation forms. Correlation of segments with tectonic faults and size and number of accumulation forms has been observed. Detailed analysis of the position of channel bars showed higher proportion of left-sided bars to the right-sided. There was $10 \%$ more left-sided bars that covered around $14 \%$ more of the channel area than the right-sided bars. This indicates a higher erosion rate happening on the right bank and higher accumulation on the left possibly caused by the impact of Coriolis force. On the other hand, however, the larger area of right side of the catchment does not align with the theory of Coriolis force, because due to more intensive lateral erosion, this side should be smaller than the left part of the catchment. Therefore, we assume that although the impact of this force is evident in the number and area of channel bars, it does not play such an important role as the catchment tectonics and lithology that influence the catchment symmetry. The evidence of this is the alternating sections of asymmetry in different parts of the catchment.

\section{References}

Barabas D, 2008. The analysis of spatial distribution of accummulation forms in the Bodva River channel. Geomorfologia Slovaca et Bohemica, 8(1): 7-15. (in Slovak)

Barabas D, Frániková J, 2009. The disparitz of spatial distribution of accumulation forms in the channels of the Bodva River and in the brook of Chotárny potok. Geographia Cassoviensis, 3(2): 17-23. (in Slovak with English summary)

Barabas D, Sýkorová J, 2007. Accumulation forms in the Bodva River channel and their spatial distribution. Geomorphologica Slovaca et Bohemica, 7(2): 58-64. (in Slovak)

Bezák V, Biely A, Broska I et al., 2009. Explanations to the General Geological Map of the Slovak Republic 
1:200,000. State Geological Institute of D. Štúr, Bratislava. (in Slovak with English Summary)

Brieeley G J, Fryirs K A, 2005. Geomorphology and River Management, Applications of the River Styles Framework. Malden: Blackwell Publishing.

Buffington J M, Montgomery D R, 1999. A procedure for classifying textural facies in gravel-bed rivers. Water Resources Research, 35(6): 1903-1914.

Bull W, McFadden L, 1977. Tectonic geomorphology north and south of the Garlock fault, California. In: Doering D O. Proceedings Vol. of 8th Annual Geomorph. Symp.: 116-138. State University of New York at Binghamton, Binghamton.

Demovič M, Menčík E, Pesl V, 1954. Preliminary results of detailed geological mapping between Nizna Radvan and Papin. Zprávy o Geologických Výzkumech vr, 1953: 8-11. (in Czech)

Dolgopolova E N, Isupova M V, 2011. Water and sediment dynamics at Saint Lawrence River Mouth. Water Resources, 38(4): 453-469.

Dzurovčin L, Harčár J, 2000. Contribution to the study of the mountain morphostructures in the Outher Flysch of Eastern Slovakia. In: Lacika J eds. 1. Konferencia Asociácie slovenských geomorfológov pri SAV 35-41. ASG, Bratislava. (in Slovak)

Dzurovčin L, Harčár J, 2002. Origin and paleogeographic evolution of the eastern Slovakia Outer Carpathians. Folia Geographica, 28(6): 232-244. (in Slovak with English Summary)

Gilbert G K, 1917. Hydraulic-mining debris in the Sierra Nevada. U.S. Geol. Surv. Prof. Pap.

Gordon N D, McMahon T A, Finlayson B L, 2004. Stream Hydrology: An Introduction for Ecologists. Chichester: John Wiley \& Sons Ltd.

Hack J, 1973. Stream profile analysis and stream gradient index. J. Res. U. S. Geol. Survey, 1(4): 421-429.

Harčár J, 2002. The role of neotectonic in the formation of the Nízke Beskydy Mts. Acta Universitatis Nicolai Copernici. Geografia, Toruń, 32(109): 69-77.

Hey R D, 1997. Stable river morphology. Applied fluvial geomorphology for river engineering and management: 223-236.

Holécyová J, Duurkovič T, 1963. Contribution to knowledge of menilite beds silicites in East-Slovakian Flysch. Geol. Práce, 27: 175-191. (in Slovak with English summary)

Hromádka J, 1956. Orografické tř́dení Československé republiky. Sborník Československé společnosti zeměpisné, Praha, 61(3): 161-180.

Jakál J, Feranec J, Harčár J et al., 1992. Using of radar images in geomorphology. Mineralia Slovaca, 24: 257-269. (in Slovak with English summary)

Jalčovíková M, Macura V, Škrovinová M et al., 2011. Determination of the impact of the depth and velocity parameters on the quality of the Aquatic habitat. Acta Hydrologica Slovaca, 12(2): 430-441.

Keller E, Pinter N, 1996. Adjustment of drainage to bed rock in region of contrasting tectonic framework. Geological Society of America Abstracts Programs, 9: 1046

Kidova A, Lehotský M, 2012. Channel changes, extreme floods, pattern, indices, braided-wandering river, the River Belá. Geographical Journal/Geografický časopis, 64(4): 311-333.

Koráb T, 1983. Geological map of the Nízke Beskydy Mts - Eastern Part (1:50,000). State Geological Institute of D. Štúr Publisher, Bratislava.

Koráb T, Ďurkovič T, 1978. Geology of Dukla Unit (East - slovakian Flysch). Publ. Geological Institute of D. Štúr. Bratislava. 194. (in Slovak with English summary)

Koráb T, Vaňová M, Snopková P, Samuel O, Duurkovič T, 1966. Základný geologický výskum na liste Stakčín 1:50,000. Technical Report, State Geological Institute of D. Štúr Pub., Bratislava, 1-72.

Lacika J, Lehotský M, 2013. Morphostructural relief analysis as a tool for comprehension of the development and changes to river networks: The example of north-eastern Slovakia. Geographical Journal, 65(3): 251-268. (in Slovak with English summary)

Lehotský M, 2005. Methodological aspects of behaviour and changes of channel-floodplain geosystems. Geomorphologia Slovaca V, 1, ASG SAV, 34-51.

Lehotský M, Grešková A, 2005. Basic classification systems and morphometric characteristics of the channel-floodplain geosystems. Geomophologia Slovaca, 5: 5-20.

Leopold L B, 1997. Water, Rivers and Creeks. University Science Books.

Leško B, 1951. Der Bau des Flyschgebietes zwischen Snina und Medzilaborce. Geologický sbornik SAV a U, Bratislava, 2: 75-84.

Leško B, 1952a. Ueber die Piraterie der UdavaZemepisný sborník SAV a U, Bratislava, 4(3/4): 89-106. (in Slovac 
with German summary)

Leško B, 1952b. Der Einfluss des Geologischen aufbaues auf das Wassernetz des Laborec. Geologický sborník $S A V$ a $U$, Bratislava, 3(1/2): 75-84. (in Slovac with German summary)

Leško B, 1952c. Geologie des äusseren Flysches zwischen Snina und Medzilaborce. Geologické práce, Sošit, Bratislava, 35: 5-69. (in Slovac with German summary)

Leško B, 1957. Geologie des Ost- und Südteiles des Ondavaer Hügellandes. Geologické práce, Zošit, Bratislava, 46: 281-322. (in Slovac with German summary)

Leško B, 1958. Flysch zwischen Medzilaborce und Pichné (Ostslowakei). Geologické práce, Zprávy, Bratislava, 14: 56-71. (in Slovac with German summary)

Leško B, Began A, Franko O et al., 1964a. Explanations to the General geological map of ČSSR 1:200 000, sheet M-34-XXIX Snina. Publ. Ústredný Ústav Geologický, Bratislava. (in Slovak)

Leško B, Kuthan M, Seneš J, 1964b. General geological map of ČSSR 1:200 000, sheet M-34-XXIX Snina. ÚGÚ, ÚÚG, Bratislava. (in Slovak)

Leško B, Samuel O, 1968. The geology of the East Slovakian Flysch. Publ. SAV, Bratislava. (in Slovak with English Summary)

Leško B, Slávik J, 1967. Les traits fondamentaux de la structure gèologique de la region située entre les Karpates Occidentales et les Karpates Orientales. Geologický Zborník SAV 18: 169-172.

Li M, Chen Z, Yin D et al., 2011. Morphodynamic characteristics of the dextral diversion of the Yangtze River mouth, China: Tidal and the Coriolis Force controls. Earth Surface Processes and Landforms, 36: 641-650.

Li M, Ge J, Kappenberg J et al., 2014. Morphodynamic processes of the Elbe River estuary, Germany: The Coriolis effect, tidal asymmetry and human dredging. Front. Earth Sci., 8(2): 181-189.

Macura V, Szolgay J, Kohnová S, 1995. Flow adjustments. Slovenská technická univerzita, Bratislava.

Matějka A, Buday T, Březina J et al., 1964a. Explanations to the General Geological Map of ČSSR 1:200,000, sheets M-34-XXII Zborov - M-34-XXVIII Košice. Publ. Ústredný Ústav Geologický, Bratislava. (in Slovak)

Matějka A, Buday T, Fusán O et al., 1964b. General geological map of ČSSR 1:200 000, sheets M-34-XXII Zborov - M-34-XXVIII Košice. ÚGÚ, Publ. Ústredný Ústav Geologický, Bratislava. (in Slovak)

Mazúr E, 1980. Typological relief division. In: Atlas SSR. SAV, SÚGaK, 50-51.

Mazúr E, Činčura J, Kvitkovič J, 1980. Geomorphology. In: Atlas SSR. SAV, SÚGaK, 46-47.

Mazúr E, Kvitkovič J, 1963. Development, current status and role of geomorphology. Acta Geologica et Geographica Universitatis Comenianae, 3, 112-128. (in Slovak with Russian and English Summary)

Mazúr E, Lukníš M, 1980. Geomorphological units. In: Atlas SSR. SAV, SÚGaK, 54-55.

Pesl V, 1964. Internal zone of the Rača Unit in Eastern Slovakia (in Czech). Zprávy o geologických výskumoch v roku 1963, Bratislava 2: 127-129.

Pesl V, Menčík E, 1959. An overview geological mapping of Magura Flysch in the Eastern Slovakia (in Czech). Zprávy o geologických výzkumech v r. 1957, Praha: 181-186.

Potfaj M, Kováčik M (Eds.), Bóna J, Žec B, Pristaš J, Maglay J, 2008. General Geological Map of the Slovak Republic 1:200,000, Map sheet 27 - Svidník. Publ. Ministry of the Environment of the Slovak Republic and State Geological Institute of D. Štúr, Bratislava.

Rosgen D L, 1994. Classification of natural rivers. Catena, 22: 169-199.

Schumm S A, Lichty R W, 1965. Time, space and causality in geomorphology. American Journal of Sciences, 263: 110-119.

Strahler A, 1952. Hypsometria (area-altitude). Analysis of erosional topography. Bulletin of the Geological Society of America, 63: 1117-1142.

ÚGKK S R, 2012. Database ÚHDP. Úrad geodézie, kartografie a katastra Slovenskej republiky, Bratislava. (in Slovak)

Unger Z, Németh I, 2013. Estimation of the Coriolis-force for Tisza River. Carpathian Journal of Earth and Environmental Sciences, 8(2): 201-208.

Vojtko R, Petro L', Benová A et al., 2012. Neotectonic evolution of the northern Laborec drainage basin (northeastern part of Slovakia). Geomorphology, 138(1): 276-294.

Žec B, Gazdačko L', Kováčik M et al., 2006. Geological map of the Nízke Beskydy Mts. - central part (1:50,000). Publ. Ministry of the Environment of the Slovak Republic and State Geological Institute of D. Štúr, Bratislava.

Žec B, Gazdačko L', Kováčik M et al., 2011. Explanations to the Geological map of the Nízke Beskydy Mts. central part at a scale 1:50,000. Publ. State Geological Institute of D. Štúr, Bratislava. (in Slovak with English Summary) 